Egyptian Journal of Aquatic Biology \& Fisheries

Zoology Department, Faculty of Science,

Ain Shams University, Cairo, Egypt.

ISSN $1110-6131$

Vol. 23(2): 195 - 212 (2019)

www.ejabf.journals.ekb.eg

\title{
Snailicidal, antimicrobial, antioxidant and anticancer activities of Beauveria bassiana, Metarhizium anisopliae and Paecilomyces lilacinus fungal extracts
}

\author{
Marwa T. A. Abdel-Wareth ${ }^{1 *}$, Mosad A. Ghareeb ${ }^{2}$, Mohamed S. Abdel-Aziz ${ }^{3}$ \\ and Ali M. El-Hagrassi ${ }^{4}$ \\ 1- Environmental Research and Medical Malacology Department, Theodor Bilharz Research \\ Institute, Egypt. \\ 2- Medicinal Chemistry, Biochemistry and Molecular Biology Department, Theodor Bilharz \\ Research Institute, Egypt \\ 3- Microbial Chemistry Dept., Genetic Engineering and Biotechnology Division, National \\ Research Center, Egypt \\ 4- Phytochemistry and Plant Systematic Dept., Pharmaceutical Industries Division, National \\ Research Centre, Egypt.
}

*Corresponding author: marwatamim2001@ hotmail.com

\section{ARTICLE INFO}

Article History:

Received: March 11, 2019

Accepted: April 20, 2019

Online: April 28, 2019

Keywords:

Entomopathogenic fungi

Paecilomyces lilacinus

B.alexandrina

Antimicrobial

Antioxidant

Anticancer

\section{ABSTRACT}

Fungi are capable of producing a wide variety of secondary metabolites. Entomopathogenic fungi along with species which parasitize nematodes represent excellent candidates for bioactive compounds production. This study aimed at exploring the snailicidal, antimicrobial and antioxidant activities of ethyl acetate and acetone extracts of Beauveria bassiana, Metarhizium anisopliae and Paecilomyces lilacinus. Ethyl acetate and acetone extracts were prepared and tested against Biomphalaria alexandrina snails, their antioxidant and antimicrobial activities were also investigated. The anticancer activity of $P$. lilacinus acetone extract was tested on hepatocellular carcinoma (HepG2) cells. Acetone extract of $P$. lilacinus $\left(\mathrm{LC}_{50}=120 \mathrm{ppm}\right)$ was more toxic to $B$. alexandrina snails than that of $B$. bassiana $\left(\mathrm{LC}_{50}=231 \mathrm{ppm}\right)$. Sublethal concentrations of both extracts adversely affected survival rate, histological pattern of digestive and hermaphrodite glands of the tested snails, besides their genotoxicity to DNA of snails. P. lilacinus acetone extract showed the highest antioxidant activity. Also, its antimicrobial activity against Staphylococcus aureus, Escherichia coli and Candida albicans was high. Moreover, it was cytotoxic to HepG2 cells $\left(\mathrm{IC}_{50}=2.81\right.$ $\mu \mathrm{g} / \mathrm{ml})$. GC/MS analysis indicated the presence of 37 compounds in $B$. bassiana acetone extract with 2-methylhept-2,6-dien-4-ol and 1,3-dimethoxy-2-(hydroxymethyl)-9h-xanthene as major compounds. While 48 compounds were identified in P. lilacinus acetone extract where hexadecanoic acid, methyl ester and 10, 13 octadecadienoic acid, methyl ester were the major compounds. In conclusion, $B$. bassiana and $P$. lilacinus are excellent sources of bioactive compounds which have multiple biological effects.

\section{INTRODUCTION}

Fungi are recognized as prolific producers of secondary metabolites which have high therapeutic value as antibiotics, cytotoxic substances, insecticides, 
compounds that promote or inhibit growth, attractors and repellents, besides their biotechnological applications (Demain, 1999; Kishore et al., 2007; Mabrouk et al., 2008; Abdel-Aziz et al., 2018). Entomopathogenic fungi are classified as fungi that infect, invade and eventually kill their insects (Singkaravanit et al., 2010). Some entomopathogenic isolates such as Metarhizium anisopliae and Beauveria bassiana have been investigated for use against a broad range of insect pests (Sheng, 2007; Ezz et al., 2008), they are environmentally friendly and not harmful to the public health, hence they have been developed and commercialized for pest control (Francardi et al., 2015).

Paecilomyces lilacinus is a soil inhabiting fungus that is capable of parasitizing nematode eggs, juveniles and females thus reducing soil population of plant parasitic nematodes. Strains of this fungus have been formulated to be applied for controlling nematodes in many countries (EPA, 2005; Kiewnick and Sikora, 2003; 2006). Also, a strain of $P$. lilacinus showed snailicidal effect against the invasive apple snail Pomacea canaliculata (Maketon et al., 2009).

Generally, diverse toxic metabolites have been described in several fungal biological control agents including Beauveria, Metarhizium and Pacilomyces (Vey et al., 2001), some of these metabolites have been found to possess antibiotic, fungicidal or insecticidal properties (Kershaw et al.,1999; Vey et al., 2001; Ross, 2005). Production of oosporein, beauvencin, bassianolide, and cyclosporine A was commonly observed in cultures of some entomopathogenic fungi (Boucias and Pendland, 1998; Strasser et al., 2000). Moreover, Parine et al. (2010) found that secondary metabolites of $B$. bassiana showed antifungal and antibacterial effects against some pathogens. Thus, the current study aimed at exploring the bioactive compounds produced by Beauveria bassiana, Metarhizium anisopliae and Paecilomyces lilacinus by studying the snailicidal, antimicrobial, antioxidant and anticancer activities of their extracts.

\section{MATERIALS AND METHODS}

\section{Maintenance and rearing of snails}

Biomphalaria alexandrina snails were obtained from irrigation canals in Kafr Hakeem area, Giza Governorate. They were maintained in glass aquaria (40 X20 $\mathrm{X} 25 \mathrm{~cm}$ ) containing dechlorinated tap water, which was changed twice weekly. The snails were kept under laboratory conditions $\left(22 \pm 2^{\circ} \mathrm{C}\right)$, and fed fresh lettuce leaves. These snails were allowed to acclimatize in the laboratory conditions three weeks before being used in experimental tests.

\section{Cultivation and extraction of fungi}

The fungi used in this work were Beauveria bassiana, Metarhizium anisopliae and Paecilomyces lilacinus. These fungal strains were obtained from the commercial products; Biover ${ }^{\odot}$, Bioranza ${ }^{\odot}$ and Bio-Nematon ${ }^{\odot}$, respectively. They were kindly provided as powders by Central Agricultural Pesticides Laboratory, Agricultural Research Center, Egypt. To get the fungal strains, one $\mathrm{g}$ of each powder was dissolved in $9 \mathrm{ml}$ sterilized distilled water and shaken well. Then, one $\mathrm{ml}$ of this mixture was transferred and spread, under aseptic condition, onto the surface of Czapek-Dox agar medium of the following composition (g/l): Sucrose (30.00), $\mathrm{NaNO}_{3}(3.0), \mathrm{MgSO}_{4}$ x $7 \mathrm{H}_{2} \mathrm{O}(0.50), \mathrm{KCl}(0.50), \mathrm{FeSO}_{4}$ x $7 \mathrm{H}_{2} \mathrm{O}(0.01), \mathrm{K}_{2} \mathrm{HPO}_{4}$ (1.0), agar (18.0), distilled water $(1000.0 \mathrm{ml})$ and the $\mathrm{pH}$ was adjusted to 6.5. The inoculated plates were incubated at $28^{\circ} \mathrm{C}$ for 7 days. Scale-up fermentation was carried out using three $1 \mathrm{~L}$ Erlenmeyer flasks for each fungus, each contains $100 \mathrm{~g}$ 
rice and $100 \mathrm{ml}$ distilled water, sterilized at $121^{\circ} \mathrm{C}(15 \mathrm{lb})$ for $20 \mathrm{~min}$. Each flask was inoculated with spore suspension from ten days old cultures. After incubation at $30^{\circ} \mathrm{C}$ for 15 days, the medium was extracted several times with ethyl acetate till exhaustion (ethyl acetate extract).The mycelial components, in the medium, were extracted by acetone followed by ethyl acetate (acetone extract) (Abdel-Aziz et al., 2018).

\section{Toxicity of fungal extracts against Biomphalaria alexandrina snails}

Six fungal extracts were used in toxicity tests to prepare a series of concentrations using dechlorinated tap water at $22 \pm 2^{\circ} \mathrm{C}$. Three replicates were used; each of ten snails (8-10 $\mathrm{mm}$ in diameter) for each concentration. The exposure period was $24 \mathrm{~h}$ followed by another $24 \mathrm{~h}$ as a recovery period. Another group of snails was maintained under the same experimental conditions as a control group (WHO, 1965). Dead snails were counted, and $\mathrm{LC}_{50}$ values of the most toxic fungal extracts were computed (Litchfield and Wilcoxon, 1949).

\section{Effect of fungal extracts on survival rate of adult snails}

This experiment was designed to explore the effect of prolonged exposure to sublethal concentrations $\left(\mathrm{LC}_{5}, \mathrm{LC}_{15}\right.$ and $\left.\mathrm{LC}_{25}\right)$ of the most effective fungal extracts on survival rate of B. alexandrina snails (8-10 mm in diameter). A group of 20 adult snails was exposed in four replicates to each sublethal concentration. A control group was maintained in clean dechlorinated tap water under the same experimental conditions. These snails were fed on dried lettuce leaves. Dead snails were removed from the containers every day and their number was recorded.

\section{Effect of fungal extracts on digestive and hermaphrodite glands of B. alexandrina} snails

Adult B. alexandrina snails (five from each treatment, $8-10 \mathrm{~mm}$ in diameter) exposed for 4 weeks to $\mathrm{LC}_{15}$ of investigated extracts were dissected. The snail shell was gently broken between two slides, shell parts were removed carefully, then the soft part was obtained and slightly washed in a drop of distilled water. The upper portion of the soft part which includes the hermaphrodite and digestive glands was cut, and immediately fixed in Bouin's solution for $24 \mathrm{~h}$. The fixed samples were dehydrated, cleared, and embedded in paraffin. Then they were sectioned serially at 5 $\mu \mathrm{m}$ and stained with hematoxylin and eosin (Mohamed and Saad, 1990).

\section{Determination of genotoxicity of fungal extracts to B. alexandrina snails using COMET assay}

Head -foot region of five snails exposed to $\mathrm{LC}_{15}$ of the effective extracts and control group were cut and kept at $-4^{\circ} \mathrm{C}$. For analysis, these samples were crushed, then transferred to one $\mathrm{ml}$ ice-cold PBS. This suspension was stirred for $5 \mathrm{~min}$. and filtered. Cell suspension $(100 \mu \mathrm{l})$ was mixed with $600 \mu \mathrm{l}$ of low-melting agarose (0.8\% in PBS). $100 \mu 1$ of this mixture was spread on pre-coated slides. The coated slides were immersed in lyses buffer (0.045 M TBE, $\mathrm{pH}$ 8.4, containing 2.5\% SDS) for $15 \mathrm{~min}$. The slides were placed in electrophoresis chamber containing the same TBE buffer, but devoid of SDS. The electrophoresis conditions were $2 \mathrm{~V} / \mathrm{cm}$ for 2 min. and $100 \mathrm{~mA}$. They were stained with ethidium bromide $(20 \mu \mathrm{g} / \mathrm{ml})$ at $4{ }^{\circ} \mathrm{C}$. The samples were investigated when they were still humid, the DNA fragment migration patterns of 100 cells for each dose level were evaluated with a fluorescence microscope (with excitation filter of $420-490 \mathrm{~nm}$ [issue $510 \mathrm{~nm}$ ]). Lengths of comet tails were measured from the middle of the nucleus to the end of the tail, and the size of the comet was determined. For visualization of DNA damage, observations were made of EtBr-stained DNA using a 40x objective on a fluorescent microscope. A Komet 5 image analysis software developed by Kinetic Imaging, Ltd. (Liverpool, 
UK) linked to a CCD camera was used to assess the quantitative and qualitative extent of DNA damage in the cells. It was carried out by measuring the length of DNA migration and the percentage of migrated DNA. Finally, the program calculated tail moment. Generally, 50 to 100 randomly selected cells were analyzed per sample.

$\%$ DNA in tail = total intensity of tail /total intensity of comet (head and tail) $\mathrm{X} 100$, and tail moment $=$ tail length X \% DNA in tail. Both \% DNA in tail and tail moment are directly proportional to DNA damage (Singh et al., 1988).

\section{Antimicrobial activity of fungal extracts}

Disc agar plate method was established to evaluate the antimicrobial activities of the six fungal extracts. Four different test microbes, Staphylococcus aureus, Escherichia coli, Candida albicans and Aspergillus niger, were selected to evaluate the antimicrobial activities as representatives of Gram+ bacteria, Gram- bacteria, yeast, and fungal groups, respectively. The bacterial and yeast test microbes were grown on nutrient agar medium. While, Aspergillus niger was cultivated on potato dextrose agar (PDA) medium. The culture of each test microbe was diluted by sterilized distilled water to $10^{7}$ to $10^{8}$ colony forming units (CFUs)/ $\mathrm{ml}$, and then 1 $\mathrm{ml}$ of each was used to inoculate $1 \mathrm{~L}$ Erlenmeyer flask containing $250 \mathrm{ml}$ of solidified agar media. These media were put onto previously sterilized Petri dishes ( $25 \mathrm{ml}$ of solidified medium/10 $\mathrm{cm}$ diameter Petri dish). Five millimeter filter paper discs loaded with $0.2 \mathrm{mg}$ of each extract were dried at room temperature under sterilized conditions. These paper discs were placed on agar plates seeded with test microbes and incubated for $24 \mathrm{~h}$, at the appropriate temperature of each test organism. Antimicrobial activities were recorded as the diameter of inhibition zones (including the disc itself) that appeared around the discs. Neomycin $(100 \mu \mathrm{g} / \mathrm{disc})$ and cyclohexamide $(100 \mu \mathrm{g} / \mathrm{disc})$ were used as antibacterial and antifungal standards, respectively (Bauer et al., 1966).

\section{Total Antioxidant Capacity (TAC) of fungal extracts}

Antioxidant activity of the six extracts was determined according to phosphomolybdenum method using ascorbic acid as a standard. This assay is based on the reduction of Mo (VI) to Mo (V) by the sample analyte and subsequent formation of a green colored [phosphate $=\mathrm{Mo}(\mathrm{V})$ ] complex at acidic $\mathrm{pH}$ with a maximal absorption at $695 \mathrm{~nm}$. In this method, $0.5 \mathrm{ml}$ of each compound $(100 \mu \mathrm{g} /$ $\mathrm{ml})$ in methanol was combined in dried vials with $5 \mathrm{ml}$ of reagent solution $(0.6 \mathrm{M}$ sulfuric acid, $28 \mathrm{mM}$ sodium phosphate and $4 \mathrm{mM}$ ammonium molybdate). The vials containing the reaction mixture were capped and incubated in a thermal block at $95^{\circ} \mathrm{C}$ for $90 \mathrm{~min}$. After the samples had cooled at room temperature, the absorbance was measured at $695 \mathrm{~nm}$ against a blank. The blank consisted of all reagents and solvents without the sample, and it was incubated under the same conditions. All experiments were carried out in triplicates. The antioxidant activity of the sample was expressed as the number of ascorbic acid equivalent (AAE) (Prieto et al., 1999).

\section{Anticancer activity of acetone extract of Paecilomyces lilacinus}

Human hepatocellular cancer cell line (HepG2) obtained from the American Type Culture Collection (ATCC, Rockville, MD) were grown on RPMI-1640 medium supplemented with $10 \%$ inactivated fetal calf serum and $50 \mu \mathrm{g} / \mathrm{ml}$ gentamycin. The cells were maintained at $37^{\circ} \mathrm{C}$ in a humidified atmosphere with $5 \%$ $\mathrm{CO}_{2}$ and were subcultured two to three times a week.

The tumor cell lines were suspended in the medium at a concentration of $5 \times 10^{4}$ cell/well in Corning® 96-well tissue culture plates, then incubated for $24 \mathrm{~h}$. The tested extract was then added into 96-well plates (three replicates) to get twelve 
concentrations for each compound. Six vehicle controls with media or $0.5 \%$ DMSO were run for each 96 well plate as a control. After incubation for $24 \mathrm{~h}$, the number of viable cells was determined by measuring the optical density at $590 \mathrm{~nm}$ with the microplate reader (SunRise, TECAN, Inc, USA). Then, this equation was applied:

The percentage of viability $=\left(\mathrm{OD}_{t} / \mathrm{OD}_{\mathrm{c}}\right) \times 100$

Where $\mathrm{OD}_{\mathrm{t}}$ is the mean optical density of wells treated with the tested sample and $\mathrm{OD}_{\mathrm{c}}$ is the mean optical density of untreated cells. The relation between surviving cells and drug concentration was plotted to get the survival curve of each tumor cell line after treatment with the specified extract. The concentration required to cause toxic effects in $50 \%$ of intact cells $\left(\mathrm{IC}_{50}\right)$, was estimated from graphic plots of the dose response curve (Mosmann, 1983; Elaasser et al., 2011).

Gas chromatography/mass spectrometry (GC/MS) analysis of fungal extracts

The GC/MS analysis of the most effective extracts was performed using a Thermo Scientific, Trace GC Ultra/ISQ Single Quadrupole MS,TG-5MS fused silica capillary column $(30 \mathrm{~m}, 0.251 \mathrm{~mm}, 0.1 \mathrm{~mm}$ film thickness). For GC/MS detection, an electron ionization system with ionization energy of $70 \mathrm{eV}$ was used, Helium gas was used as the carrier gas at a constant flow rate of $1 \mathrm{ml} / \mathrm{min}$. The injector and MS transfer line temperature was set at $280^{\circ} \mathrm{C}$. The oven temperature was programmed to an initial temperature of $50^{\circ} \mathrm{C}$ (hold $2 \mathrm{~min}$ ) to $150{ }^{\circ} \mathrm{C}$ at an increasing rate of $7^{\circ} \mathrm{C} / \mathrm{min}$. then to 270 at an increasing rate of $5^{\circ} \mathrm{C} / \mathrm{min}$ (hold $2 \mathrm{~min}$ ) then to $310^{\circ} \mathrm{C}$ as a final temperature at an increasing rate of $3.5^{\circ} \mathrm{C} / \mathrm{min}$ (hold $10 \mathrm{~min}$ ). The quantification of all the identified components was investigated using a percent relative peak area. A tentative identification of the compounds was performed based on the comparison of the irrelative retention time and mass spectra with those of the NIST, WILLY library data of the GC/MS system.

\section{Statistical analysis}

Student t-test was used to determine the significance of difference between each two treatments, and between each treatment and control group in COMET assay test. ANOVA was used to determine the significance of difference between treatment groups in antioxidant test. All statistical analyses were carried out using SPSS v. 17.0 for Windows.

\section{RESULTS}

\section{Toxicity of fungal extracts against Biomphalaria alexandrina snails}

Only acetone extracts of Beauveria bassiana and Paecilomyces lilacinus had molluscicidal effect on $B$. alexandrina snails, as $P$. lilacinus was more toxic than $B$. bassiana, with $\mathrm{LC}_{50}$ values of 120 and 231 ppm, respectively (Table 1).

Table 1. The values of $\mathrm{LC}_{50}$ and sublethal concentrations of effective fungal extracts on adult $B$. alexandrina snails after $24 \mathrm{~h}$ of exposure.

\begin{tabular}{cccccccc}
\hline \multicolumn{3}{c}{$\begin{array}{c}\text { Beauveria bassiana acetone } \\
\text { extract }(\mathbf{p p m})\end{array}$} & \multicolumn{4}{c}{$\begin{array}{c}\text { Paecilomyces lilacinus acetone } \\
\text { extract }(\mathbf{p p m})\end{array}$} \\
\hline $\mathrm{LC}_{5}$ & $\mathrm{LC}_{15}$ & $\mathrm{LC}_{25}$ & $\mathrm{LC}_{50}$ & $\mathrm{LC}_{5}$ & $\mathrm{LC}_{15}$ & $\mathrm{LC}_{25}$ & $\mathrm{LC}_{50}$ \\
23 & 69 & 115 & 231 & 12 & 36 & 60 & 120 \\
\hline
\end{tabular}

Effect of sublethal concentrations of acetone extracts of Beauveria bassiana and Paecilomyces lilacinus on survival rate of Biomphalaria alexandrina snails

Generally, survival rate of snails exposed to acetone extract of B. bassiana was lower than that of snails exposed to acetone extract of $P$. lilacinus. The survival rate 
of snails exposed to $\mathrm{LC}_{5}(23 \mathrm{ppm})$ and $\mathrm{LC}_{25}(115 \mathrm{ppm})$ of $B$. bassiana extract reached $20 \%$ at the $4^{\text {th }}$ week of exposure compared to $80 \%$ for control snails (Figs. $1 \mathrm{a} \mathrm{\&} \mathrm{b}$ ).

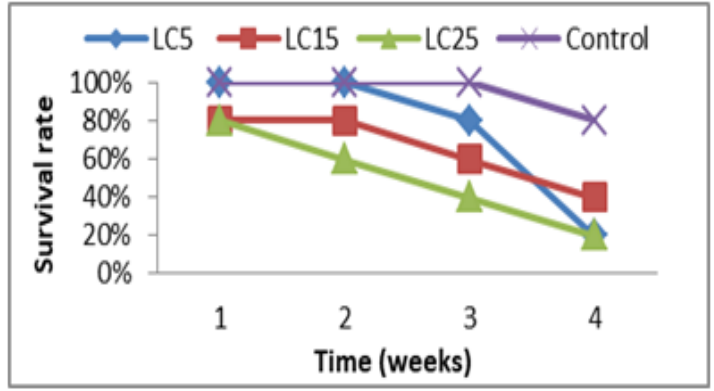

a

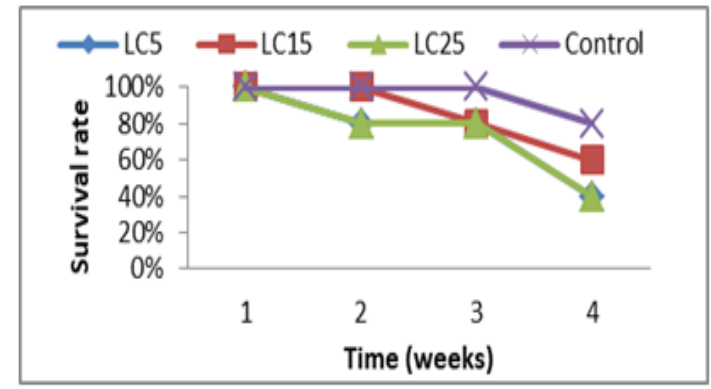

b

Fig. 1. Effect of sublethal concentrations of (a) B. bassiana acetone extract and (b) P. lilacinus acetone extract on survival rate of $B$. alexandrina snails

\section{Effect of fungal extracts on digestive and hermaphrodite glands of Biomphalaria alexandrina snails}

Fig. (2a) shows that normal digestive gland consists of a number of tubules; each tubule contains two types of cells; digestive cells and secretory cells. Exposure of snails to $\mathrm{LC}_{15}(69 \mathrm{ppm})$ of $B$. bassiana acetone extract resulted in extensive vacuolation of digestive cells, and degeneration of secretory ones (Fig. 2b). Also, the effect of $\mathrm{LC}_{15}(36 \mathrm{ppm})$ of $P$. lilacinus acetone extract was vacuolation of digestive cells, but some vacuoles contained certain secretions. Moreover, rupture of tubular membrane and degeneration of secretory cells and connective tissue were observed (Fig. 2c).
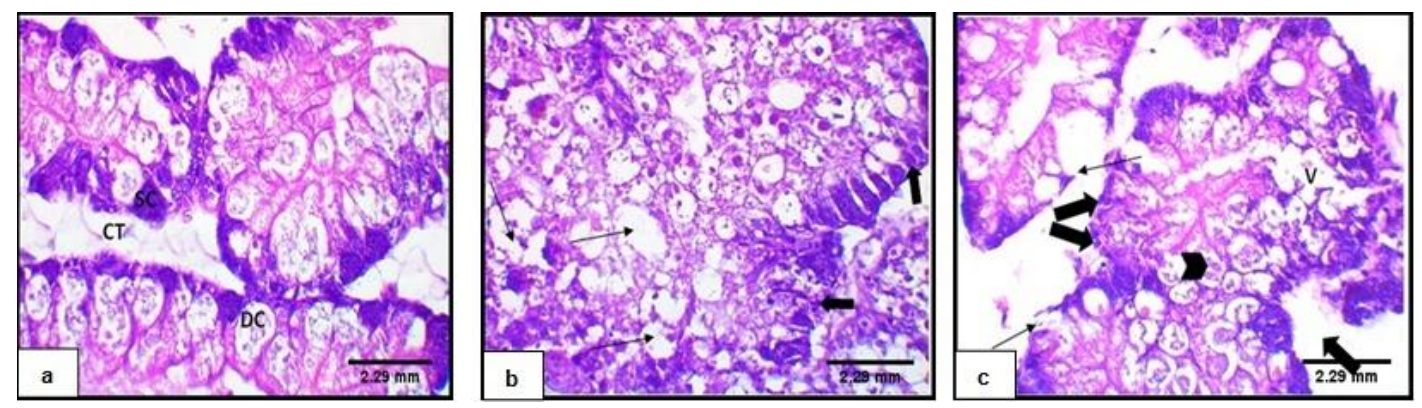

Fig. 2: Photomicrographs of T.S. in the digestive gland of Biomphalaria alexandrina snails. a, normal B. alexandrina snails showing tubules containing digestive cells (DC) and secretory cells (SC), connective tissue (CT) between tubules; b, snails exposed to $\mathrm{LC}_{15}$ of $B$. bassiana acetone extract showing vigorous vacuolation of digestive cells (thin arrows), irregular shape of tubules and degeneration of secretory cells (thick arrows); c, snails exposed to $\mathrm{LC}_{15}$ of $P$. lilacinus acetone extract showing rupture of tubular membrane (thin arrows), vacuolation of digestive cells (V), some vacuoles contain certain secretions (head arrow), secretory cells and connective tissue between tubules are degenerated (thick arrows)

Regarding hermaphrodite gland, the normal one consists of a number of acini; each acinus contains the stages of oogenesis (primary oocytes, secondary oocytes and mature ova) and spermatogenesis (primary spermatocytes, secondary spermatocytes and sperms) (Fig. 3a). Exposure of snails to $\mathrm{LC}_{15}$ of $\mathrm{B}$. bassiana acetone extract resulted in a number of deleterious effects on the gland, as few secondary spermatocyes were scattered in the acinus, they were either degenerated or 
densely stained without differentiation between their cytoplasmic inclusions and nuclei (Fig. 3b). Exposure to $\mathrm{LC}_{15}$ of $P$. lilacinus acetone extract resulted in vacancy of the acinus, as only secondary spermatocytes were found (Fig. 3c).
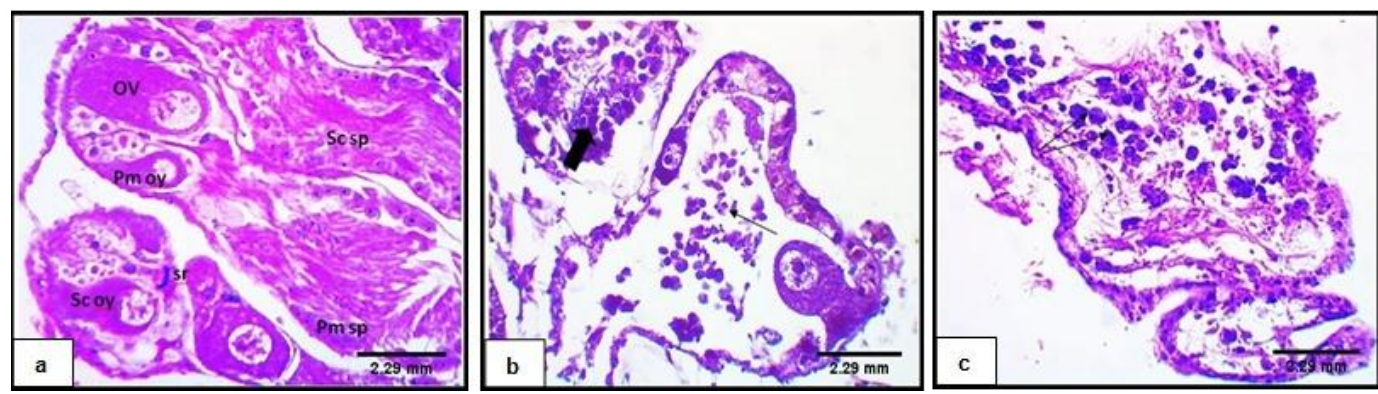

Fig. 3: Photomicrographs of T.S. in the hermaphrodite gland of Biomphalaria alexandrina snails. a, normal B. alexandrina snails showing primary oocyte (Pm oy), secondary oocyte (Sc oy) and mature ovum $(\mathrm{OV})$, primary spermatocytes (Pm sp), secondary spermatocytes (Sc sp) and sperms (sr); b, snails exposed to $\mathrm{LC}_{15}$ of $\mathrm{B}$. bassiana acetone extract showing degenerated secondary spermatocytes (thin arrow) and densely stained ones without differentiation between their cytoplasmic inclusions and nuclei (thick arrow); c, snails exposed to $\mathrm{LC}_{15}$ of P. lilacinus acetone extract showing the presence of only secondary spermatocytes (arrows).

\section{Genotoxicity of fungal extracts to Biomphalaria alexandrina snails}

Results in Table (2) and Fig. (4) showed the effect of $\mathrm{LC}_{15}$ of B. bassiana and P.lilacinus acetone extracts on DNA of snails. There was a significant difference in the values of tail moment between these two treatments as the highest tail moment was recorded in the DNA of snails exposed to $\mathrm{LC}_{15}$ of $B$. bassiana acetone extract. Both extracts resulted in noticeable DNA damage compared to control group, whereas $B$. bassiana acetone extract was more genotoxic than that of $P$. lilacinus.

Table 2: Significance of difference in comet assay results of B. alexandrina snails.

\begin{tabular}{|c|c|c|c|c|c|}
\hline Extract & $\begin{array}{c}\text { Tailed } \\
\%\end{array}$ & $\begin{array}{c}\text { Untailed } \\
\%\end{array}$ & $\begin{array}{l}\text { Tail length } \\
(\mu \mathrm{m})\end{array}$ & $\begin{array}{c}\text { Tail DNA } \\
\%\end{array}$ & $\begin{array}{l}\text { Tail Moment } \\
\text { (UNIT) }\end{array}$ \\
\hline $\begin{array}{l}\mathrm{LC}_{15} \text { of Beauveria bassiana } \\
\text { acetone extract }\end{array}$ & 7 & 93 & $2.48 \pm 0.05^{* \mathrm{a}}$ & 2.39 & $5.93 \pm 0.03 *^{\mathrm{a}}$ \\
\hline $\begin{array}{l}\mathrm{LC}_{15} \text { of Paecilomyces lilacinus } \\
\text { acetone extract }\end{array}$ & 9 & 91 & $2.55 \pm 0.02 *^{\mathrm{a}}$ & 2.29 & $5.84 \pm 0.01 * b$ \\
\hline Control & 4 & 96 & $1.16 \pm 0.01^{\mathrm{b}}$ & 1.26 & $1.46 \pm 0.02^{\mathrm{c}}$ \\
\hline
\end{tabular}

*The result is significantly different from control at $P<0.05$

Different letters in the same column indicate significant difference at $P<0.05$, while similar letters indicate no significant difference
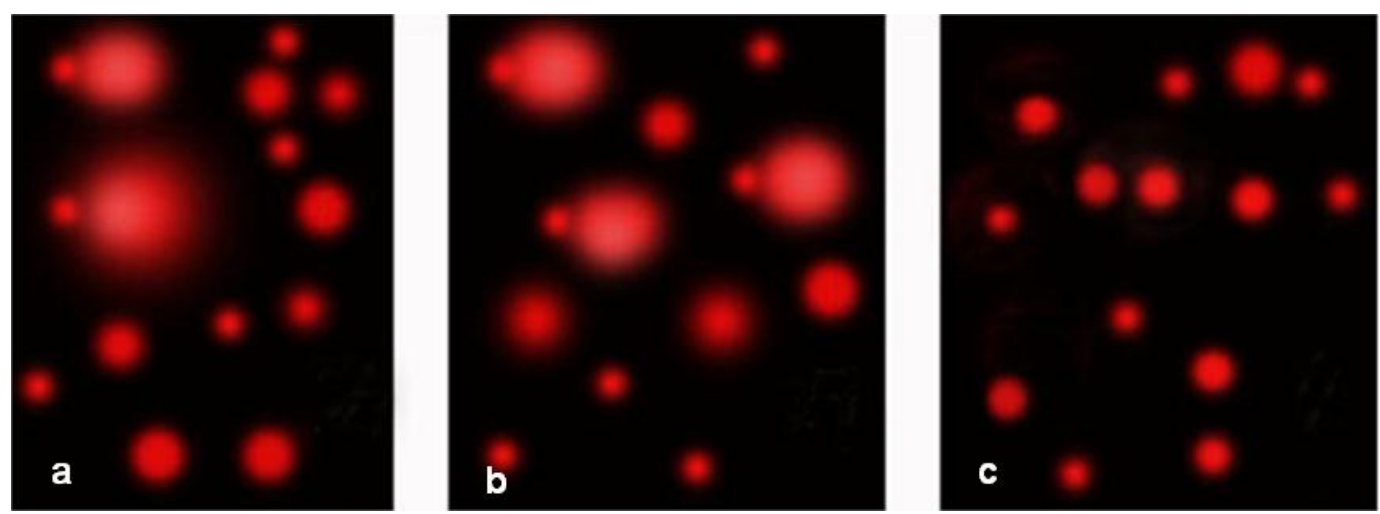

Fig. 4: Comet assay of $B$. alexandrina snails showing (a) snails exposed to $\mathrm{LC}_{15}$ of $B$. bassiana acetone extract, (b) snails exposed to $\mathrm{LC}_{15}$ of P. lilacinus acetone extract and (c) control snails 


\section{Antimicrobial activity of fungal extracts}

Acetone extracts of Paecilomyces lilacinus and Metarhizium anisopliae showed the highest activities against the tested bacterial strains and Candida albicans. The diameters of inhibition zones for Staphylpcoccus aureus, Escherichia coli and $C$. albicans treated with P. lilacinus acetone extract were 17, 18 and $18 \mathrm{~mm}$, respectively. While $M$. anisopliae acetone extract resulted in 14, 16 and $19 \mathrm{~mm}$ inhibition zones against $S$. aureus, E. coli and C. albicans, respectively (Table 3).

Table 3: Antimicrobial activity of ethyl acetate and acetone extracts of the fungal strains grown on rice medium

\begin{tabular}{lcccc}
\hline \multirow{2}{*}{ Sample } & \multicolumn{4}{c}{ Inhibition zone (mm) } \\
\cline { 2 - 5 } & $\begin{array}{c}\text { Staphylococcus } \\
\text { aureus }\end{array}$ & $\begin{array}{c}\text { Escherichia } \\
\text { coli }\end{array}$ & $\begin{array}{c}\text { Candida } \\
\text { albicans }\end{array}$ & $\begin{array}{c}\text { Aspergillus } \\
\text { niger }\end{array}$ \\
\hline EtOAc of M. anisopliae & 10 & 7 & 8 & 0 \\
EtOAc of B. bassiana & 9 & 6 & 7 & 0 \\
EtOAc of P. lilacinus & 9 & 9 & 9 & 0 \\
Acetone of M. anisopliae & 14 & 16 & 19 & 0 \\
Acetone of B. bassiana & 8 & 6 & 6 & 0 \\
Acetone of P. lilacinus & 17 & 18 & 18 & 0 \\
Neomycin & 23 & 22 & 19 & 0 \\
Cyclohexamide & 0 & 0 & 0 & 28 \\
\hline
\end{tabular}

\section{Total Antioxidant Capacity (TAC) of fungal extracts}

Table (4) shows that the highest antioxidant capacity was that of Paecilomyces lilacinus acetone extract (154.49), followed by Beauveria bassiana acetone extract (82.39).

Table 4: Total antioxidant capacity (TAC) of fungal extracts

\begin{tabular}{lc}
\hline \multicolumn{1}{c}{ Sample } & $\begin{array}{c}\text { Total antioxidant capacity }(\mathrm{mg} \\
\text { AAE/g dry extract) }\end{array}$ \\
\hline EtOAc of M. anisopliae & $46.81 \pm 3.24^{*}$ \\
EtOAc of B. bassiana & $61.79 \pm 5.62^{*}$ \\
EtOAc of $P$. lilacinus & $76.77 \pm 7.06^{*}$ \\
Acetone extract of $M$. anisopliae & $77.71 \pm 3.24^{*}$ \\
Acetone extract of B. bassiana & $82.39 \pm 5.58^{*}$ \\
Acetone extract of $P$. lilacinus & $154.49 \pm 2.81^{*}$ \\
\hline
\end{tabular}

${ }^{1}$ Results are (Mean \pm SD) $(n=3)$

${ }^{2}$ AAE: Ascorbic acid equivalent

*All the results are significantly different from each other at $P<0.05$.

\section{Anticancer activity of Paecilomyces lilacinus acetone extract}

The results demonstrated that $P$. lilacinus acetone extract exhibited high inhibitory activity against $\mathrm{HepG} 2$ cells as $\mathrm{IC}_{50}$ was $2.81 \mu \mathrm{g} / \mathrm{ml}$ (Fig. 5).

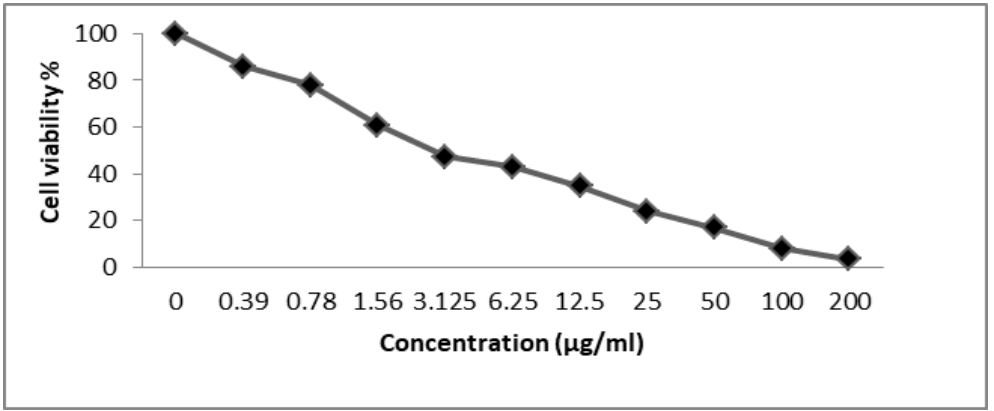


Fig. 5: Effect of $P$. lilacinus acetone extract on HepG2 cell line viability

\section{Gas chromatography/mass spectrometry (GC/MS) analysis of effective fungal extracts}

GC/MS analysis indicated that B. bassiana acetone extract consists of 37 compounds. The total peak area of the detected compounds is $98.5 \%$. The probabilities of the structures of the detected compounds are listed in Table (5), where the major peak areas were $41.59 \%$ for 2-methylhept-2,6-dien-4-ol $\left(\mathrm{C}_{8} \mathrm{H}_{14} \mathrm{O}\right)$ which is an alkene derivative and $33.85 \%$ for 1,3-dimethoxy-2- (hydroxymethyl)9h-xanthene $\left(\mathrm{C}_{16} \mathrm{H}_{16} \mathrm{O}_{4}\right)$ (Fig. 6a).

Table 5: GC/MS analysis of Beauveria bassiana acetone extract

\begin{tabular}{|c|c|c|c|c|c|}
\hline $\begin{array}{l}\text { Peak } \\
\text { No. }\end{array}$ & $\mathbf{R}_{t}(\mathbf{m i n})$ & MW & MF & $\begin{array}{c}\text { Area } \\
\%\end{array}$ & Identified compounds \\
\hline 1 & 10.11 & 126 & $\mathrm{C}_{8} \mathrm{H}_{14} \mathrm{O}$ & 41.59 & 2-Methylhept-2,6-dien-4-ol \\
\hline 2 & 11.93 & 142 & $\mathrm{C}_{9} \mathrm{H}_{18} \mathrm{O}$ & 0.13 & 7-methyl-6-octen-3-ol \\
\hline 3 & 20.86 & 284 & $\mathrm{C}_{16} \mathrm{H}_{13} \mathrm{ClN}_{2} \mathrm{O}$ & 0.21 & $\begin{array}{l}\text { 2H-1,4-Benzodiazepin-2-one,7-chloro-1,3-dihydro-1 } \\
\text {-methyl-5-phenyl- }\end{array}$ \\
\hline 4 & 25.22 & 414 & $\mathrm{C}_{30} \mathrm{H}_{54}$ & 0.65 & $\begin{array}{l}\text { Cyclohexane, 1,1',1",1"'-(1,6-hexanediylidene) } \\
\text { tetrakis- }\end{array}$ \\
\hline 5 & 25.71 & 542 & $\mathrm{C}_{40} \mathrm{H}_{62}$ & 0.32 & Phytofluene \\
\hline 6 & 28.12 & 354 & $\mathrm{C}_{10} \mathrm{H}_{10} \mathrm{Br}_{2} \mathrm{~F}_{2} \mathrm{~N}_{2}$ & 0.14 & 2,6-Dibromo-3,5-difluoro-4-piperidinylpyridine \\
\hline 7 & 29.15 & 376 & $\mathrm{C}_{22} \mathrm{H}_{37} \mathrm{BO}_{4}$ & 1.08 & $\begin{array}{l}\text { Pregnane-3,11,20,21-tetrol, cyclic20,21-(methylboro } \\
\text { nate),(3à,5à,11á,20S) }\end{array}$ \\
\hline 8 & 29.52 & 242 & $\mathrm{C}_{15} \mathrm{H}_{30} \mathrm{O}_{2}$ & 1.11 & Tetradecanoic acid, methyl ester \\
\hline 9 & 30.98 & 366 & $\mathrm{C}_{26} \mathrm{H}_{54}$ & 0.57 & Octadecane, 3-ethyl-5-(2-ethylbutyl) \\
\hline 10 & 31.57 & 228 & $\mathrm{C}_{14} \mathrm{H}_{28} \mathrm{O}_{2}$ & 0.21 & Tetradecanoic acid \\
\hline 11 & 33.22 & 490 & $\mathrm{C}_{35} \mathrm{H}_{70}$ & 0.38 & 17-Pentatriacontene \\
\hline 12 & 33.76 & 272 & $\mathrm{C}_{16} \mathrm{H}_{16} \mathrm{O}_{4}$ & 33.85 & 1,3-dimethoxy-2-(hydroxymethyl)-9h-xanthene \\
\hline 13 & 34.80 & 300 & $\mathrm{C}_{17} \mathrm{H}_{32} \mathrm{O}_{4}$ & 1.25 & Nonanedioic acid,dibutyl ester \\
\hline 14 & 35.01 & 310 & $\mathrm{C}_{22} \mathrm{H}_{46}$ & 3.48 & Docosane \\
\hline 15 & 35.32 & 362 & $\mathrm{C}_{26} \mathrm{H}_{50}$ & 0.17 & Cyclohexane,1,1'-dodecylidenebis[4-methyl- \\
\hline 16 & 35.70 & 298 & $\mathrm{C}_{19} \mathrm{H}_{38} \mathrm{O}_{2}$ & 2.07 & Octadecanoic acid, methyl ester \\
\hline 17 & 36.09 & 378 & $\mathrm{C}_{27} \mathrm{H}_{54}$ & 0.13 & Cyclohexane,1,3,5-trimethyl-2-octadecyl- \\
\hline 18 & 36.91 & 294 & $\mathrm{C}_{19} \mathrm{H}_{34} \mathrm{O}_{2}$ & 0.28 & Methyl 10-trans,12-cis-octadecadienoate \\
\hline 19 & 37.14 & 296 & $\mathrm{C}_{19} \mathrm{H}_{36} \mathrm{O}_{2}$ & 0.16 & 16-Octadecenoic acid, methyl ester \\
\hline 20 & 38.22 & 562 & $\mathrm{C}_{38} \mathrm{H}_{74} \mathrm{O}_{2}$ & 3.50 & Oleic acid, eicosyl ester \\
\hline 21 & 38.68 & 366 & $\mathrm{C}_{26} \mathrm{H}_{54}$ & 0.22 & Octadecane, 3-ethyl-5-(2-ethylbutyl) \\
\hline 22 & 40.30 & 408 & $\mathrm{C}_{29} \mathrm{H}_{60}$ & 0.14 & Nonacosane (CAS) \\
\hline 23 & 42.00 & 290 & $\mathrm{C}_{23} \mathrm{H}_{14}$ & 0.20 & 8H-Benzo[g]cyclopenta[mno]chrysene \\
\hline 24 & 42.66 & 354 & $\mathrm{C}_{21} \mathrm{H}_{38} \mathrm{O}_{4}$ & 1.07 & $\begin{array}{lll}\begin{array}{l}\text { 9,12-Octadecadienoic } \\
\text { dihydroxypropyl ester }\end{array} & \text { acid (Z,Z)-, } & 2,3- \\
\end{array}$ \\
\hline 25 & 42.73 & 356 & $\mathrm{C}_{21} \mathrm{H}_{40} \mathrm{O}_{4}$ & 1.73 & 2,3-Dihydroxypropylelaidate \\
\hline 26 & 43.42 & 304 & $\mathrm{C}_{21} \mathrm{H}_{24} \mathrm{~N}_{2}$ & 0.37 & $\begin{array}{l}\text { trans-2-Methyl-2-phenyl-1-tert-butyl-1,2-dihydroaze } \\
\text { to[2,1-b]quinazoline }\end{array}$ \\
\hline 27 & 43.85 & 490 & $\mathrm{C}_{35} \mathrm{H}_{70}$ & 0.26 & 17-Pentatriacontene \\
\hline 28 & 44.36 & 390 & $\mathrm{C}_{24} \mathrm{H}_{38} \mathrm{O}_{4}$ & 0.41 & 2-Benzenedicarboxylic acid, \\
\hline 29 & 45.19 & 460 & $\mathrm{C}_{25} \mathrm{H}_{21} \mathrm{BrN}_{2} \mathrm{O}_{2}$ & 0.14 & $\begin{array}{l}\text { 2-(3-Bromophenyl)-3,3- } \\
\text { diphenyl-4-ethoxycarbonyl-5-amino-3H-pyrrole }\end{array}$ \\
\hline 30 & 46.07 & 610 & $\mathrm{C}_{27} \mathrm{H}_{30} \mathrm{O}_{16}$ & 0.18 & Lucenin 2 \\
\hline 31 & 46.60 & 356 & $\mathrm{C}_{21} \mathrm{H}_{40} \mathrm{O}_{4}$ & 0.67 & 9-Octadecenoic acid (Z)- \\
\hline 32 & 47.71 & 378 & $\mathrm{C}_{22} \mathrm{H}_{34} \mathrm{O}_{5}$ & 0.44 & Benzenedodecanoic acid \\
\hline 33 & 48.28 & 548 & $\mathrm{C}_{30} \mathrm{H}_{44} \mathrm{O}_{9}$ & 0.14 & $\begin{array}{l}\text { Carda-4,20(22)-dienolide,3-[(6-deoxy-3-O-methyl-à- } \\
\text { D-allopyranosyl)oxy]-1,14-dihydroxy-, (1á,3á)- }\end{array}$ \\
\hline 34 & 49.15 & 354 & $\mathrm{C}_{23} \mathrm{H}_{46} \mathrm{O}_{2}$ & 0.14 & Docosanoic acid, methyl ester \\
\hline 35 & 50.41 & 357 & $\mathrm{C}_{17} \mathrm{H}_{12} \mathrm{BrNOS}$ & 0.55 & $\begin{array}{l}\text { 2-[à-(p-bromophenyl)-á-mercaptoethenyl]isoquinoli } \\
\text { n-1-(2H)-one }\end{array}$ \\
\hline 36 & 52.02 & 442 & $\mathrm{C}_{26} \mathrm{H}_{34} \mathrm{O} 6$ & 0.43 & Dihydrodeacetylgedunin \\
\hline 37 & 52.32 & 414 & $\mathrm{C}_{29} \mathrm{H}_{50} \mathrm{O}$ & 0.13 & Stigmast-5-en-3-ol,(3á,24S)- \\
\hline
\end{tabular}

$\mathrm{R}_{\mathrm{t}}$ : Retention time; MW: Molecular weight; MF: Molecular formula 
Paecilomyces lilacinus acetone extract consists of 48 compounds (Table 6 and Fig. 6b). The total peak area of the detected compounds is $99.98 \%$. The probabilities of the structures of the detected compounds are listed in Table (6), where the major peak areas were $54.59 \%$ for hexadecanoic acid, methyl ester $\left(\mathrm{C}_{17} \mathrm{H}_{34} \mathrm{O}_{2}\right)$ and $28.05 \%$ for 10,13-octadecadienoic acid, methyl ester $\left(\mathrm{C}_{19} \mathrm{H}_{34} \mathrm{O}_{2}\right)$, they are fatty acid methyl esters.

Table 6: GC/MS analysis of Paecilomyces lilacinus acetone extract

\begin{tabular}{|c|c|c|c|c|c|}
\hline Peak No. & $\mathbf{R}_{\mathrm{t}}(\mathbf{m i n})$ & MW & MF & Area \% & Identified compounds \\
\hline 1 & 9.97 & 135 & $\mathrm{C}_{8} \mathrm{H}_{6} \mathrm{D}_{3} \mathrm{NO}$ & 0.10 & N-Phenylacetamide \\
\hline 2 & 11.94 & 143 & $\mathrm{C}_{7} \mathrm{H}_{13} \mathrm{NO}_{2}$ & 0.06 & 7-Methoxy-1-aza-8-oxabicyclo(5.1.3)octane \\
\hline 3 & 13.77 & 420 & $\mathrm{C}_{24} \mathrm{H}_{36} \mathrm{O}_{6}$ & 0.01 & $\begin{array}{l}\text { 8,14-Seco-3,19-epoxyandrostane-8,14-dione,17-acetoxy-3á-me } \\
\text { thoxy-4,4-dimethyl }\end{array}$ \\
\hline 4 & 18.56 & 442 & $\mathrm{C}_{30} \mathrm{H}_{50} \mathrm{O}_{2}$ & 0.01 & Lanosta-8,24-diene-3,22-diol \\
\hline 5 & 20.31 & 308 & $\mathrm{C}_{20} \mathrm{H}_{36} \mathrm{O}_{2}$ & 0.04 & Z,Z-3,15-Octadecadien-1-ol acetate \\
\hline 6 & 20.79 & 145 & $\mathrm{C}_{7} \mathrm{H}_{15} \mathrm{NO}_{2}$ & 0.11 & Heptane, 1-nitro- \\
\hline 7 & 22.51 & 354 & $\mathrm{C}_{23} \mathrm{H}_{46} \mathrm{O}_{2}$ & 0.03 & Docosanoic acid, methyl ester \\
\hline 8 & 22.96 & 186 & $\mathrm{C}_{10} \mathrm{H}_{18} \mathrm{O}_{3}$ & 0.14 & Nonanoic acid, 9-oxo-, methyl ester \\
\hline 9 & 23.72 & 70 & $\mathrm{C}_{3} \mathrm{H}_{6} \mathrm{~N}_{2}$ & 0.01 & 2-(Methylimino)acetonitrile \\
\hline 10 & 25.06 & 294 & $\mathrm{C}_{19} \mathrm{H}_{34} \mathrm{O}_{2}$ & 0.11 & 17-Octadecynoic acid, methyl ester \\
\hline 11 & 25.60 & 216 & $\mathrm{C}_{11} \mathrm{H}_{20} \mathrm{O}_{4}$ & 0.14 & Nonanedioic acid, dimethyl ester \\
\hline 12 & 25.83 & 196 & $\mathrm{C}_{10} \mathrm{H}_{12} \mathrm{O}_{4}$ & 0.04 & Benzoic acid, 2,6-dimethoxy-, methylester \\
\hline 13 & 26.53 & 310 & $\mathrm{C}_{22} \mathrm{H}_{46}$ & 0.04 & Docosane \\
\hline 14 & 26.74 & 296 & $\mathrm{C}_{19} \mathrm{H}_{36} \mathrm{O}_{2}$ & 0.04 & Cyclopentanetridecanoic acid, methyl ester \\
\hline 15 & 27.37 & 224 & $\mathrm{C}_{13} \mathrm{H}_{20} \mathrm{O}_{3}$ & 0.07 & Methyl jasmonate \\
\hline 16 & 27.93 & 366 & $\mathrm{C}_{24} \mathrm{H}_{46} \mathrm{O}_{2}$ & 0.03 & Cyclopropanedodecanoic acid, 2-octyl-, methyl ester \\
\hline 17 & 28.48 & 251 & $\mathrm{C}_{18} \mathrm{H}_{21} \mathrm{~N}$ & 0.03 & 3,6,9-Triethylcarbazole \\
\hline 18 & 28.60 & 310 & $\mathrm{C}_{20} \mathrm{H}_{38} \mathrm{O}_{2}$ & 0.04 & cis-13-Eicosenoic acid \\
\hline 19 & 29.11 & 224 & $\mathrm{C}_{14} \mathrm{H}_{24} \mathrm{O}_{2}$ & 0.44 & 12-Tridecynoic acid, methyl ester \\
\hline 20 & 29.55 & 242 & $\mathrm{C}_{15} \mathrm{H}_{30} \mathrm{O}_{2}$ & 1.41 & Methyl tetradecanoate \\
\hline 21 & 30.21 & 400 & $\mathrm{C}_{29} \mathrm{H}_{52}$ & 0.05 & Benzene,2-(1-decylundecyl)-1,4-dimethyl- \\
\hline 22 & 30.84 & 266 & $\mathrm{C}_{19} \mathrm{H}_{38}$ & 0.02 & 1-Nonadecene \\
\hline 23 & 31.30 & 296 & $\mathrm{C}_{19} \mathrm{H}_{36} \mathrm{O}_{2}$ & 0.01 & 4-Octadecenoic acid, methyl ester \\
\hline 24 & 31.63 & 256 & $\mathrm{C}_{16} \mathrm{H}_{32} \mathrm{O}_{2}$ & 0.18 & Pentadecanoic acid, methyl ester \\
\hline 25 & 33.36 & 268 & $\mathrm{C}_{17} \mathrm{H}_{32} \mathrm{O}_{2}$ & 0.18 & 11-Hexadecenoic acid, methyl ester \\
\hline 26 & 34.00 & 270 & $\mathrm{C}_{17} \mathrm{H}_{34} \mathrm{O}_{2}$ & 54.59 & Hexadecanoic acid, methyl ester \\
\hline 27 & 34.93 & 378 & $\mathrm{C}_{27} \mathrm{H}_{54}$ & 0.01 & Cyclohexane, 1,3,5-trimethyl-2-octadecyl- \\
\hline 28 & 35.01 & 266 & $\mathrm{C}_{17} \mathrm{H}_{30} \mathrm{O}_{2}$ & 0.03 & Hexadecadienoic acid, methyl ester \\
\hline 29 & 35.20 & 282 & $\mathrm{C}_{18} \mathrm{H}_{34} \mathrm{O}_{2}$ & 0.02 & Methyl 9-heptadecenoate \\
\hline 30 & 35.31 & 282 & $\mathrm{C}_{18} \mathrm{H}_{34} \mathrm{O}_{2}$ & 0.16 & cis-10-Heptadecenoic acid, methyl ester \\
\hline 31 & 35.64 & 284 & $\mathrm{C}_{18} \mathrm{H}_{36} \mathrm{O}_{2}$ & 0.20 & Heptadecanoic acid, methyl ester \\
\hline 32 & 36.92 & 294 & $\mathrm{C}_{19} \mathrm{H}_{34} \mathrm{O}_{2}$ & 0.04 & 9,12-Octadecadienoic acid, methyl ester, (E,E)- \\
\hline 33 & 37.44 & 294 & $\mathrm{C}_{19} \mathrm{H}_{34} \mathrm{O}_{2}$ & 28.05 & 10,13-Octadecadienoic acid, methyl ester \\
\hline 34 & 37.50 & 296 & $\mathrm{C}_{19} \mathrm{H}_{36} \mathrm{O}_{2}$ & 12.62 & 4-Octadecenoic acid, methyl ester \\
\hline 35 & 37.66 & 298 & $\mathrm{C}_{16} \mathrm{H}_{26} \mathrm{O}_{5}$ & 0.52 & Dimethyl ester of pentylurofuranoic acid isomer \\
\hline 36 & 39.03 & 256 & $\mathrm{C}_{16} \mathrm{H}_{20} \mathrm{~N}_{2} \mathrm{O}$ & 0.03 & 1-Propyl-2-methyl-7-methoxy-5H,6H-pyrido[3,4-b]indole \\
\hline 37 & 39.34 & 310 & $\mathrm{C}_{21} \mathrm{H}_{42} \mathrm{O}$ & 0.05 & 11-Heneicosanone \\
\hline 38 & 39.79 & 346 & $\mathrm{C}_{18} \mathrm{H}_{35} \mathrm{BrO}$ & 0.05 & Octadecanal, 2-bromo- \\
\hline 39 & 40.41 & 400 & $\mathrm{C}_{21} \mathrm{H}_{36} \mathrm{O}_{7}$ & 0.01 & $\begin{array}{l}\text { Propanoic acid, 2-[5-(2-hydroxypropyl) } \\
\text { tetrahydrofuran-2-yl]-,1-[5-(1-methoxy-1-oxopropan-2-yl)tetra } \\
\text { hydrofuran-2-yl]propan-2-yl ester }\end{array}$ \\
\hline 40 & 40.74 & 312 & $\mathrm{C}_{19} \mathrm{H}_{36} \mathrm{O}_{3}$ & 0.03 & Oxiraneoctanoic acid, 3-octyl-, methyl ester,cis \\
\hline 41 & 41.64 & 346 & $\mathrm{C}_{17} \mathrm{H}_{18} \mathrm{~N}_{2} \mathrm{O}_{6}$ & 0.01 & N-Nitrosohemanthidine \\
\hline 42 & 42.92 & 242 & $\mathrm{C}_{16} \mathrm{H}_{34} \mathrm{O}$ & 0.03 & 2-Hexadecanol \\
\hline 43 & 43.06 & 246 & $\mathrm{C}_{14} \mathrm{H}_{14} \mathrm{O}_{4}$ & 0.01 & [1,1'-Biphenyl]-4,4'-diol, 3,3'-dimethoxy- \\
\hline 44 & 43.44 & 256 & $\mathrm{C}_{15} \mathrm{H}_{32} \mathrm{OSi}$ & 0.07 & 1-Ethyl-1-octyloxy-1-silacyclohexane \\
\hline 45 & 43.55 & 271 & $\mathrm{C}_{17} \mathrm{H}_{21} \mathrm{NO}_{2}$ & 0.03 & $\begin{array}{l}\text { 7-[4-(N-Ethyl-N-(2-hydroxyethyl)amino]phenyl]penta-2,4,6-tri } \\
\text { en-1-al }\end{array}$ \\
\hline 46 & 43.78 & 185 & $\mathrm{C}_{8} \mathrm{H}_{8} \mathrm{ClNO}_{2}$ & 0.02 & Benzoic acid, 2-amino-6-chloro-, methyl ester \\
\hline 47 & 44.33 & 390 & $\mathrm{C}_{24} \mathrm{H}_{38} \mathrm{O}_{4}$ & 0.04 & 1,2-Benzenedicarboxylic acid,bis(2-ethylhexyl) ester \\
\hline 48 & 54.32 & 429 & $\mathrm{C}_{26} \mathrm{H}_{23} \mathrm{NO}_{5}$ & 0.02 & $\begin{array}{l}\text { 12-Phenyl-2,3,7,8-tetramethoxy-5H-(1)-benzopyrano[4,3-c]iso } \\
\text { quinoline }\end{array}$ \\
\hline
\end{tabular}

$\mathrm{R}_{\mathrm{t}}$ : Retention time; MW : Molecular weight; MF: Molecular formula 

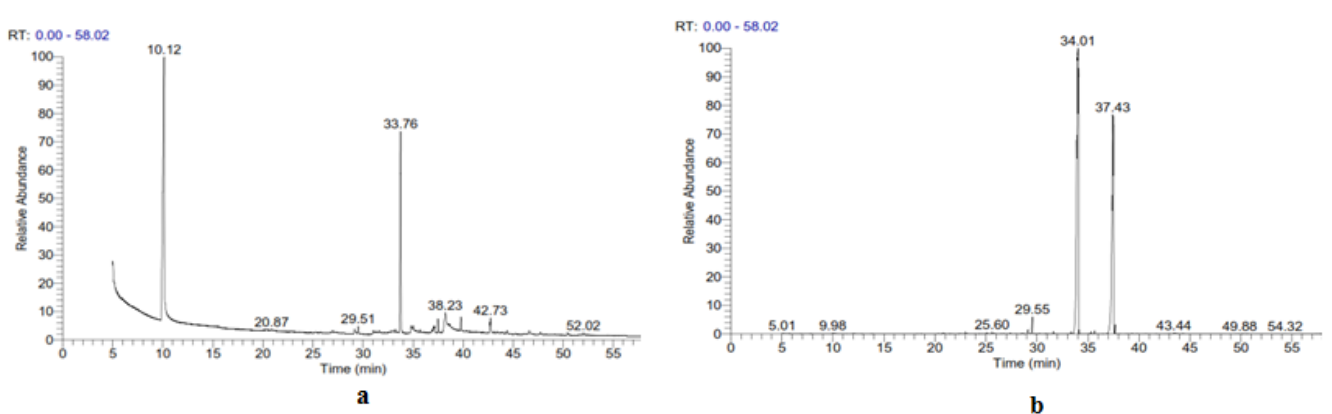

Fig. 6: GC/MS analysis of (a ) B. bassiana acetone extract, (b) P. lilacinus acetone extract.

\section{DISCUSSION}

Schistosomiasis is one of the infectious diseases that affect more than $90 \%$ of people in the African region (WHO, 2016); the life cycle of the worm necessitates the presence of intermediate hosts which are Biomphalaria alexandrina snails. Reducing the numbers of these snails, or debilitating their ability to reproduce is one of the main targets of controlling programs in which chemical molluscicides are currently applied (WHO, 2008). Seeking molluscicidal substances of biological origin is urgently needed to eliminate harmful effects of chemical compounds on both human health and its environment (Oliveria-Filho and Paumgartten, 2000). The present results showed that acetone extract of Paecilomyces lilacinus was more toxic to B. alexandrina snails than that of Beauveria bassiana, with $\mathrm{LC}_{50}$ values of 120 and $231 \mathrm{ppm}$, respectively. This is in agreement with previous studies which showed that some fungal species were toxic to B. alexandrina snails such as Aspergillus fumigatus, A. terreus and Penicillium janthinellum (Osman et al., 2013; Saad et al., 2014).

The current work showed that survival rate of snails exposed to acetone extract of $B$. bassiana was lower than that of snails exposed to acetone extract of $P$. lilacinus. These results are in coincidence with the findings of Osman et al. (2013) who demonstrated that the survival rate of B. alexandrina treated with Aspergillus fumigatus extract was reversely proportional to the concentration. Moreover, Saad et al. (2014) found that after 4 weeks of $B$. alexandrina exposure to $\mathrm{LC}_{15}$ and $\mathrm{LC}_{25}$ of Aspergillus terreus filtrate, their survival rate decreased to $50 \%$, while the survival rate of snails exposed to $\mathrm{LC}_{25}$ of Penicillium janthinellum filtrate decreased sharply to $45 \%$.

When digestive gland cells which are analogous to hepatic cells are stressed by a xenobiotic, they undergo a series of irreversible histopathological changes, and their study can give indications of the degree of toxicity to the organism (Viarengo and Canesi, 1991). The present results demonstrated that exposure of snails to $B$. bassiana and $P$. lilacinus acetone extracts resulted in vacuolation of digestive cells, and degeneration of secretory ones. These results match the findings of Lajtner et al. (1996) on the effect of phenol on digestive gland of Amphimelania holandrii snails. The vacoulation of digestive cells was closely related to the digestive and absorptive 
processes going on in these cells (Ibrahim et al., 2006). These processes increase in snails exposed to molluscicides, and hence, the degree of cytoplasmic vacuolation increases. Hamed et al. (2007) studied the ultrastructural changes induced by two carbamate molluscicides on the digestive gland of the snail Eobania vermiculata, and found severe cytoplasmic vacuolization. Moreover, exposure of B. alexandrina snails to Mirazid resulted in necrosis of connective tissue, digestive tubules lost their normal shape, and noticeable vacuoles were detected in both secretory and digestive cells (Osman et al., 2014).

Exposure of snails to $B$. bassiana and P. lilacinus acetone extracts in the current study resulted in a number of deleterious effects on the hermaphrodite gland. Our results are in agreement with Saad et al. (2014), they found that the more adverse effect on hermaphrodite gland of $B$. alexandrina was that exhibited by $\mathrm{LC}_{15}$ of Penicillium janthinellum filtrate, where acini lost their architecture and became shrunk. Also, when B. alexandrina snails were exposed to Artemether (dihydroartemisinin methyl ether) for 21 days, a complete destruction of gametogenic cells and severe damage of ovotestis took place (Mossalem et al., 2013).

Comet assay is a rapid and sensitive technique that detects DNA strand breaks, measuring the migration of DNA from immobilized individual cell nuclei (Fairbairn et al., 1995). It was applied on a wide variety of aquatic species including snails (Sarkar et al., 2015; Ibrahim et al., 2018). This technique is considered one of the most promising genotoxicity biomarkers as it needs a small number of cells and detects damage at single cell level (Bolognesi and Cirillo, 2014). The present work showed that $\mathrm{LC}_{15}$ of both $B$. bassiana and P. lilacinus acetone extracts resulted in noticeable DNA damage. Moreover, $B$. bassiana acetone extract was the most genotoxic. To the best of our knowledge, this is the first study to evaluate the genotoxic effect of fungal extracts on $B$. alexandrina snails using comet assay. Previous studies were concerned with the effect of chemical substances; Sarkar et al. (2015) evaluated the genotoxicity of cadmium chloride in Nerita chamaeleon, and Ibrahim et al. (2018) reported high DNA migration in B. alexandrina snails exposed to lufenuron insecticide.

In the current work, acetone extracts of Paecilomyces lilacinus and Metarhizium anisopliae were highly active against the tested bacterial strains and Candida albicans. This result is very promising and could be explained according to Hepsibah and Jothi (2017) who reported superior antibacterial activity of acetone extract over ethyl acetate one. The present findings are in coincidence with Lee $e t$ al. (2005), they declared that a number of $M$. anisopliae strains and Paecilomyces spp. were highly effective on $S$. aureus. In addition, dichloromethane extract of $M$. anisopliae showed higher antibacterial activity against $E$. coli than $S$. aureus (Ravindran et al., 2014). Ethyl acetate extract of $M$. anisopliae showed moderate antimicrobial effect on C. albicans (Fabelico, 2015). Moreover, Mohammadi et al. (2016) stated that the extracellular metabolites of two strains of P. lilacinus showed antifungal activity against Saccharomyces cerevisiae. Similarly, Gulwani et al. (2015) demonstrated that Paecilomyces fumosoroseus metabolites showed the highest activity against E. coli, Bacillus subtilis and Salmonella typhi.

Oxidative stress is a great health problem leading to several health disorders such as cancer, cardiovascular and liver diseases. This phenomenon is due to an overproduction of free radicals and consequent accumulation of reactive species. Several studies have demonstrated that natural bioactive chemical ingredients derived from medicinal plants and fungal extracts have a great capability to remove hazards of such reactive species and thus are considered promising natural 
antioxidant agents (Ghareeb et al., 2018 a, 2018 b). The present study demonstrated that the highest antioxidant capacity was that of Paecilomyces lilacinus acetone extract, followed by Beauveria bassiana acetone extract. These findings are in agreement with Zhang et al. (2010) and Kiran and Mohan (2018), they showed that different extracts of $B$. bassiana have high antioxidant capacity. Regarding $P$. lilacinus, to the best of our knowledge, this is the first study to evaluate the antioxidant activity of its extracts.

According to the American Cancer Institute (USNCI), the crude extracts are considered potent anticancer agents when their $\mathrm{IC}_{50}$ values are less than $20 \mu \mathrm{g} / \mathrm{ml}$ (Suffness and Pezzuto, 1990; Boik, 2001). Cancer is considered the third cause of death after cardiovascular and infectious diseases (Shaikh et al., 2014; Doll and Peto, 2003). From the point of controlling the side effects of chemical drugs used in the treatment of cancer, seeking drugs of natural origin becomes mandatory. Hepatocellular carcinoma (HepG2) cells represent one of the most widely used experimental models for in vitro studies on liver cancer (Haggag et al., 2011). Our results are in accordance with previous results on cytotoxic activity of entomopathogenic fungi; Zhang et al. (2004) demonstrated that the cytotoxic activity of ethyl acetate extracts of Cordyceps sinensis on human leukemia cell line was high. Also, a noticeable cytotoxic activity of the entomopathogenic fungus Hirsutella sp. ethyl acetate extract was recorded against Chinese hamster ovary cells at $100 \mu \mathrm{g} / \mathrm{ml}$. A significant cytotoxic activity of Beauveria feline was reported against leukaemia, melanoma and colon cancer cell lines. Recently, Kiran and Mohan (2018) demonstrated that ethyl acetate extract of B. bassiana showed the highest cytotoxic activity against lung carcinoma. Also, Abdel-Hady et al. (2016) found that ethyl acetate extracts of both Aspergillus tamarii and Penicillium islandicum showed high cytotoxic effect on HepG2 cells.

The present GC/MS analysis of the effective extracts showed that on the one hand, B. bassiana acetone extract consists of 37 compounds, where the major compounds were 2-methylhept-2,6-dien-4-ol which is an alkene derivative and 1,3-dimethoxy-2-(hydroxymethyl)-9h-xanthene. Chibale et al. (2003) declared that xanthene derivatives are essential heterocyclic compounds in medicinal chemistry because of their biological properties as they exhibit anti-inflammatory and antibacterial activities. In addition, Ma et al. (2016) reported that four alkenes isolated from the plant Murraya koenigiithem showed significant antioxidant activities. On the other hand, Paecilomyces lilacinus acetone extract consists of 48 compounds where the major compounds were hexadecanoic acid, methyl ester and 10,13-octadecadienoic acid, methyl ester, they are fatty acid methyl esters. Antibacterial and antifungal activities of fatty acids methyl esters were previously reported (Agoramoorthy et al., 2007; Chandrasekaran et al., 2008). Sharma et al. (2014) recorded the presence of phenolic and alcoholic compounds in the filtrate of $P$. lilacinus, to which the nematicidal activity of this strain was attributed.

\section{CONCLUSION}

In conclusion, Paecilomyces lilacinus acetone extract is very promising as it showed the highest activities as snailicidal, antimicrobial, antioxidant and anticancer agent followed by Beauveria bassiana acetone extract. Metarhizium anisopliae acetone extract also exhibited high antimicrobial activity. 
Abdel-Aziz, M. S.; Ghareeb, M. A., Saad A. M.; Refahy, L. A.; Hamed, A. A. (2018). Chromatographic isolation and structural elucidation of secondary metabolites from the soil-inhabiting fungus Aspergillus fumigatus 3T-EGY. Acta Chromatogr., 30: 243-249.

Abdel-Hady, H.; Abdel-Wareth, M.T.A.; El-Wakil, E.A. and Helmy, E.A. (2016). Identification and evaluation of antimicrobial and cytotoxic activities of Penicillium islandicum and Aspergillus tamarii ethyl acetate extracts. World J. Pharm. Pharm. Sci., 5: 2021-2039.

Agoramoorthy, G.; Chandrasekaran, M.; Venkatesalu, V. and Hsu, M. J. (2007) Antibacterial and antifungal activities of fatty acid methyl esters of the blindyour-eye mangrove from India. Braz. J. Microbiol., 38: 739-42.

Bauer, A.W.; Kirby, W.M.; Sherris, J.C. and Turck, M. (1966) Antibiotic susceptibility testing by a standardized single disk method. Am. J. Clin. Pathol., 45: 493-496.

Boik, J. (2001). Natural Compounds in Cancer Therapy. Oregon Medical Press, Minnesota, USA.

Bolognesi, C. and Cirillo, S. (2014). Genotoxicity biomarkers in aquatic bioindicators. Curr. Zool., 60: 273-284.

Boucias, D.G. and Pendland, J.C. (1998). Principles of Insect Pathology, Kluwer Academic Publishers, Boston, USA.

Chandrasekaran, M.; Kannathasan, K. and Venkatesalu, V. (2008). Antimicrobial activity of fatty acid methyl esters of some members of Chenopodiaceae. Zeitschrift für Naturforschung C, 63: 331-336.

Chibale, K.; Visser, M.; Schalkwyk, D.V.; Smith, P.J.; Saravanamuthu, A. and Fairlamb, A.H. (2003). Exploring the potential of xanthene derivatives as trypanothione reductase inhibitors and chloroquine potentiating agents. Tetrahedron, 59: 2289-2296.

Demain, A.L. (1999). Pharmaceutically active secondary metabolites of microorganisms. Appl. Microbiol. Biotechnol., 52: 455-463.

Doll, R. and Peto, R. (2003). Malignant diseases. In: "Text Book of Medicine.", fourth ed. Oxford University Press, USA, pp. 483-484.

Elaasser, M.M.; Abdel-Aziz, M.M. and El-Kassas, R.A. (2011). Antioxidant, antimicrobial, antiviral and antitumor activities of pyranone derivative obtained from Aspergillus candidus. J. Microbiol. Biotech. Res., 1: 5-17.

EPA US (Environmental Protection Agency (2005). Paecilomyces lilacinus strain 251; exemption from the requirement of a tolerance. United States Federal Register, 70: 19278-19283.

Ezz, N.A.; Hameida, I.A.; El-Shabrawy, H.A.; El-Sahn, O.M.N.I. and Helmy, I.E. (2008). Evaluation of the entomopathogenic fungus Beauveria bassiana (Balsamo) as a biocontrol agent against the soft scale insect, Saissetia coffeae (Walker) (Homotera:Coccidae). Egypt J. Biol. Pest Cont., 18: 75-80.

Fabelico, F.L. (2015). The phytochemical and antimicrobial properties of entomopathogenic fungi in Nueva Vizcaya, Philippines. Asia Pac. J. Multidisciplinary Res., 3: 126-133.

Fairbairn, D.W., Olive, P.L. and O’Neill, K.L. (1995). The comet assay: A comprehensive review. Mutat. Res., 339: 37-59.

Francardi, V.; Benvenuti, C.; Barzanti, G.P. and Roversi, F. (2015). Metarhizium anisopliae biopesticides and fungus isolates: Control efficacy against 
Rhynchophorus ferrugineus (Olivier) (Coleoptera: Dryophthoridae) on different contamination substrata. J. Zool., 98: 25-29.

Ghareeb, M.A.; Mohamed, T.; Saad, A.M.; Refahy, L.A.; Sobeh, M.; Wink M, et al. (2018a). HPLC-DAD-ESI-MS/MS analysis of fruits from Firmiana simplex (L.) and evaluation of their antioxidant and antigenotoxic properties. J. Pharm. Pharmacol., 70:133-142.

Ghareeb, M.; Saad, A.; Ahmed, W.; Refahy, L. and Nasr S. (2018b). HPLC-DAD-ESI-MS/MS characterization of bioactive secondary metabolites from Strelitzia nicolai leaf extracts and their antioxidant and anticancer activities in vitro. Pharmacogn. Res., 10: 368-378.

Gulwani, N.; Shukla, H. and Sandhu,S. S. (2015). Screening the antibacterial potential of Paecilomyces fumosoroseus against some pathogenic bacteria. Open J. Adv. Drug Delivery, 3: 24-31.

Haggag, E.G.; Kamal, A.M.; Abdelhady, M.I.; El-Sayed, M.M.; El-Wakil, E.A. and Abd-El-hamed, S.S. (2011). Antioxidant and cytotoxic activity of polyphenolic compounds isolated from the leaves of Leucenia leucocephala. Pharm. Biol., 49: 1103-1113.

Hamed, S.S.; Abdelmeguied, N.E.; Essawy, A.E.; Radwan, M.A. and Hegazy, A.E. (2007). Histological and ultrastructural changes induced by two carbamate molluscicides on the digestive gland of Eobania vermiculata. J. Biol. Sci., 7:1017-1037.

Hepsibah, A. H. and Jothi, G. J. (2017). A comparative study on the effect of solvents on the phytochemical profile and biological potential of Ormocarpum cochinchichinese Auct. Non (Lour.) Merrill. Int. J. Pharm. Pharm. Sci., 9: 6772.

Ibrahim, A.M.; Sayed, S.S. and Shalash, I. R. (2018). Toxicological assessment of lambda-cyhalothrin and acetamiprid insecticides formulated mixture on hatchability rate, histological aspects, and protein electrophoretic pattern of Biomphalaria alexandrina (Ehrenberg, 1831) snails. Environ. Sci. Pollut. Res., 25: 32582-32590.

Ibrahim, A.M.; Ibrahim, W.L.F and Abou-Aouf , A.H. (2006). Ultrastructural study of the effect of a plant molluscicide (Solanum elaegnifolium) on the digestive and hermaphrodite glands of Biomphalaria alexandrina. Egypt. J. Aquat. Biol. Fish., 10:1-22.

Kershaw, M.J.; Moorhouse, E.R.; Bateman, R.; Reynolds, S.E. and Charnley, A.K. (1999). The role of destruxins in the pathogenicity of Metarhizium anisopliae for three species of insects. J. Invertebr. Pathol., 74: 213-223.

Kiewnick, S. and Sikora, R. A. (2003). Efficacy of Paecilomyces lilacinus (strain 251) for the control of root-knot nematodes. Comm. Appl. Biol. Sci., 68: 123128.

Kiewnick, S. and Sikora, R.A. (2006). Evaluation of Paecilomyces lilacinus strain 251 for the biological control of the northern root-knot nematode Meloidogyne hapla Chitwood. Nematol., 8: 69-78.

Kiran, K. and Mohan, C. M. (2018). Antioxidant and cytotoxic activity of Beauveria bassiana crude mycelia extracts against A-549 cell line. Indian J. Pharm. Sci., 80: 776-780.

Kishore, K.H.; Misra, S.; Chandra, D.R. and Prakash, K. V. (2007). Antimicrobial efficacy of secondary metabolities from Glomerella cingulata. Brazilian J. Microbiol., 38: 150-152. 
Lajtner, J.; Erben, R. and Klobucar, G.I.V. (1996). Histopathological effects of Phenol on the digestive gland of Amphimelania holandri Fer. (Gastropoda, Prosobranchia). Bull. Environ. Contam. Toxicol., 57: 458-464.

Lee, S. Y.; Nakajima, I.; Ihara, F.; Kinoshita, H. and Nihira, T. (2005). Cultivation of entomopathogenic fungi for the search of antibacterial compounds. Mycopathol.,160: 321-325.

Litchfield, J.T. and Wilcoxon, F. (1949). A simplified method of evaluating doseeffect experiments. J. Pharmacol. Exp. Ther., 96: 99-113.

Ma, Q.G.; Xu, K.; Sang, Z.P.; Wei, R.R.; Liu, W.M.; Su, Y.L.; ... , Li, L.J. (2016). Alkenes with antioxidative activities from Murraya koenigii (L.) Spreng. Bioorg. Med. Chem. Lett., 26: 799-803.

Mabrouk, A. M.; Kheiralla, Z. H.; Hamed, E.R.; Youssry, A.A. and Abd El Aty, A. (2008). Production of some biologically active secondary metabolities from marine-derived fungus Varicosporina ramulosa. Malaysian J. Microbiol., 4: 14-24.

Maketon, M.; Suttichart, K. and Domhom, J. (2009). Effective control of invasive apple snail (Pomacea canaliculata Lamarck) using Paecilomyces lilacinus (Thom) Samson. Malacol., 51:181-190.

Mohammadi, S.; Soltani, J. and Piri, K. (2016). Soilborne and invertebrate pathogenic Paecilomyces species show activity against pathogenic fungi and bacteria. J. Crop Prot., 5: 377-387.

Mohamed, S.H. and Saad, A. A. (1990). Histological studies on the hermaphrodite gland of Lymnaea caillaudi and Biomphalaria alexandrina upon infection with certain larval trematodes. Egypt. J. Histol., 13: 47-53.

Mosmann, T. (1983). Rapid colorimetric assay for cellular growth and survival: application to proliferation and cytotoxicity assays. J. Immunol. Meth., 65: 5563.

Mossalem, H.S.; Abdel-Hamid, H. and El-Shinnawy, N.A. (2013). Impact of artemether on some histological and histochemical parameters in Biomphalaria alexandrina. Afr. J. Pharm. Pharmacol., 7: 2220-2230.

Oliveria-Filho, E. C. and Paumgartten, F.J. (2000). Toxicity of Euphorbia milii latex and Niclosamide to snails and nontarget aquatic species. Ecotoxicol. Environ. Safety, 46:342-350.

Osman, G.Y.; Mohamed, A.M.; Abdel Kader, A. and Mohamed, A. A. (2013). Biological and biochemical impacts of the fungal extract of Aspergillus fumigatus on Biomphalaria alexandrina snails infected with Schistosoma mansoni. Biosci., 7: 473-485.

Osman, G.Y.; Mohamed, A.H.; Sheir, S. K., Hassab EL-Nabi, S.E. and Allam, S.A. (2014). Molluscidal activity of mirazid on Biomphalaria alexandrina snails: biological and molecular studies. Internat. J. Advan. Res., 2: 977-989.

Parine, N.R.; Pathan, A.K.; Sarayu, B.; Nishanth, V.S. and Bobbarala, V. (2010). Antibacterial efficacy of secondary metabolites from entomopathogenic fungi Beauveria Bassiana. Int. J. Chem. Anal. Sci., 1: 94-96.

Prieto, P.; Pineda, M. and Aguilar, M. (1999). Spectrophotometric quantation of antioxidant capacity through the formation of a phosphomolybdenum complex: Specific application to the determination of vitamin E. Anal. Biochem., 269: 337- 341.

Ravindran, K.; Sathishkumar, G.; Rajkuberan, C. and Sivaramakrishnan, S. (2014). Antibacterial activity of indigenous entomopathogenic fungus 
Metarhizium anisopliae against clinically isolated human pathogens. Int. J. Pharm. Pharmac. Sci., 6: 179-182.

Ross, C. F. (2005). Extracellular compounds having antibacterial properties produced by the entomopathogenic fungus Beauveria bassiana. $\mathrm{Ph} \mathrm{D}$, Oklahoma State Univ., pp. 700.

Saad, A.E.; Khalil, M.T.; Ragab, F.M.; Mekawey, A.A. and Abdel-Wareth, M.T. (2014). Efficacy of the fungi Aspergillus terreus and Penicillium janthinellum as biological control agents against Biomphalaria alexandrina snails. Int. J. Environ. Sci. Eng., 5: 25-37.

Sarkar, A.; Bhagat, J.; Ingole, B.S.; Rao, D.P. and Markad, V.L. (2015). Genotoxicity of cadmium chloride in the marine gastropod Nerita chamaeleon using comet assay and alkaline unwinding assay. Environ. Toxicol., 30:177187.

Shaikh, R.; Pund, M.; Dawane, A. and Iliyas, S. (2014). Evaluation of anticancer, antioxidant and possible anti-inflammatory properties of selected medicinal plants used in Indian traditional medication. J. Trad. Compl. Med., 4: 253-257.

Sharma, A.; Sharma, S. and Dalela, M. (2014). Nematicidal activity of Paecilomyces lilacinus 6029 cultured on Karanja cake medium. Microb. Pathog., 75: 16-20.

Sheng, K.S. (2007). Current status of biopesticides, development, farmer's acceptance and utilization and future perspective in Taiwan. Extension Bull. Food and Fertilizer Technology Center 599, 20 pp.

Singh, N. P.; McCoy, M.T.; Tice, R.R. and Schneider, E.L. (1988). A simple technique for quantitation of low levels of DNA damage in individual cells. Exp. Cell Res., 175: 184-191.

Singkaravanit, S.; Kinoshita, H.; Ihara, F. and Nihira, T. (2010). Geranylgeranyl diphosphate synthase genes in entomopathogenic fungi. Appl. Microbiol., 85: 1463-1472.

Strasser, H.; Abenstein, D.; Stupper, H. and Butt, T.M. (2000). Monitoring the distribution of secondary metabolites produced by the entomogenous fungus Beauveria brongniartii particular reference to oosporein. Microbiol. Res.,104: 1227-1233.

Suffness, M. and Pezzuto, J.M. (1990). Assays related to cancer drug discovery. In:" Methods in Plant Biochemistry, Assays for Bioactivity." Hostettmann, K. (Ed.). Academic Press, London, pp. 71-133.

Vey, A.; Hoagland, R. and Butt, T.M. (2001). Toxic metabolites of fungal biocontrol agents. In: "Fungal Biocontrol Agents." Butt, T.M.; Jackson and Magan, N. (Eds.). Progress Problem and Potential. CABI, Wallingford pp. 311-346.

Viarengo, A. and Canesi, L. (1991). Mussels as biological indicators of pollution. Aquac., 94: 225-243.

WHO (1965). Molluscicide screening and evaluation. Bull. World Healt. Org. Monograph Ser., 50: 124-138.

WHO (2008). African Network for drug/diagnostics discovery and innovation (ANDI) 'Creating a sustainable platform for R\&D innovation in Africa'.; $1^{\text {st }}$ meeting, Abuja, Nigeria.

WHO (2016). Schistosomiasis: number of people treated worldwide in 2014. Weekly Epidemiological Record 91, 53-60. Available at: http://www.who.int/wer/2016/ wer 9105.pdf.

Zhang, C.; Wang, J.; Yang, H.; Wei, D.; Hu, F. and Fan, M. (2010). Evaluation on the antioxidant activity of extracts from strains of Beauveria 
bassiana.Zhongguo Weishengtaxixue Zazhi/Chinese J. Microecol., 22:417419.

Zhang, Q.; Wu, J.; Hu, Z. and Li, D. (2004). Induction of HL-60 apoptosis by ethyl acetate extract of Cordyceps sinensis fungal mycelium. Life Sci., 75: 2911-2919.

\section{ARABIC SUMMARY}

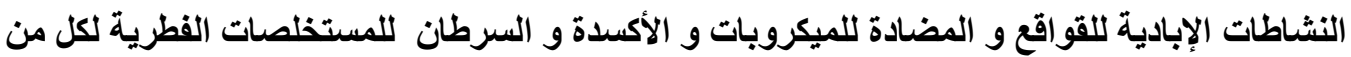
بوفاريا باسياناو ميتاريزيوم أنيسوبليى و بايسلومايسيس ولئيس ليلاسيناس

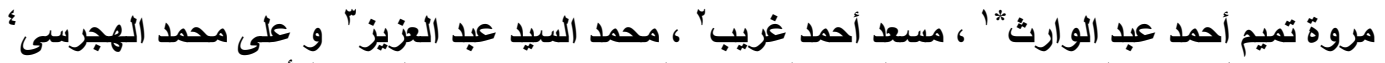

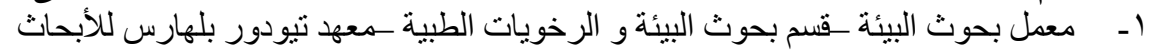

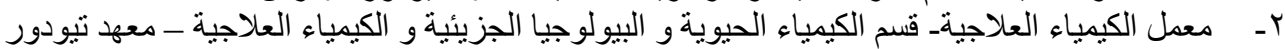

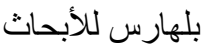

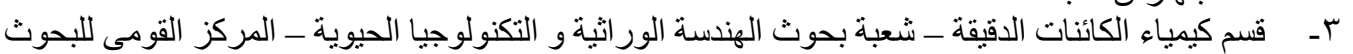

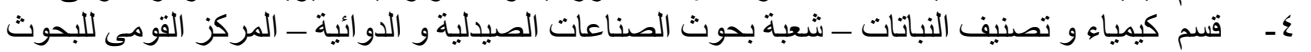

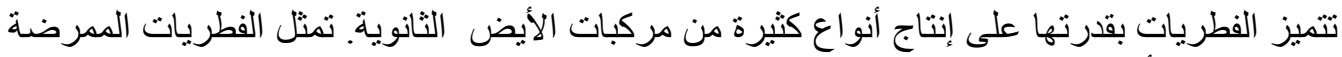

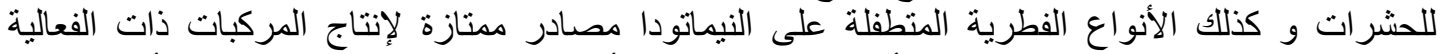

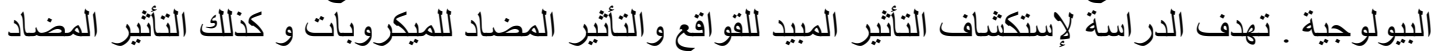

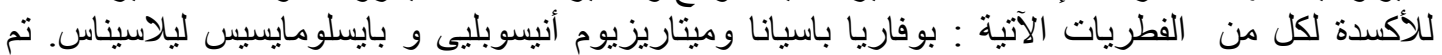

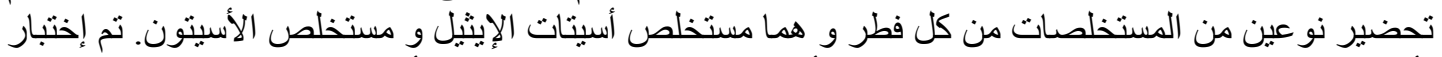

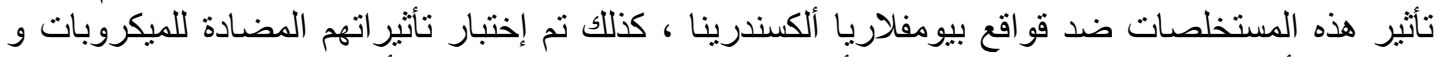

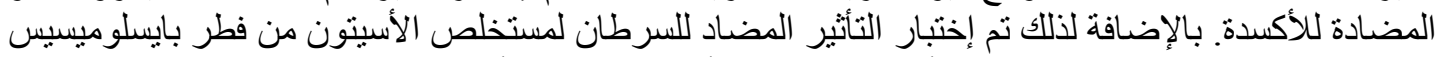

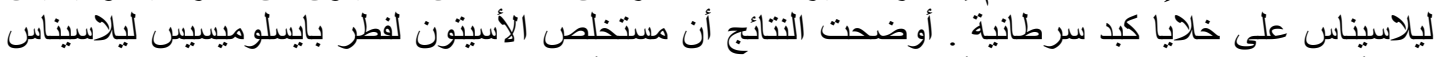

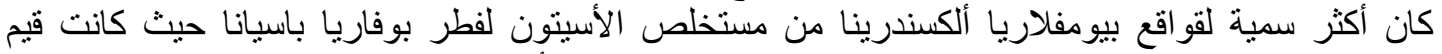

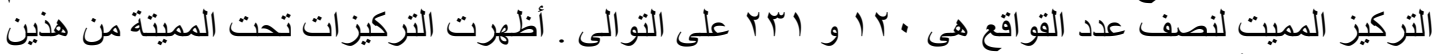

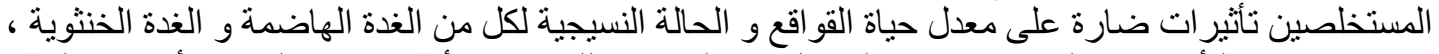

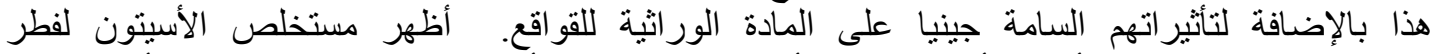

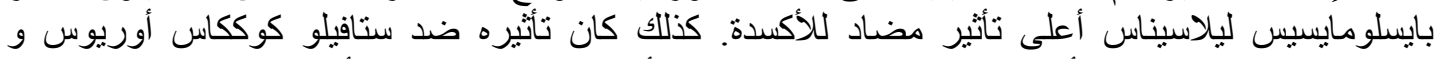

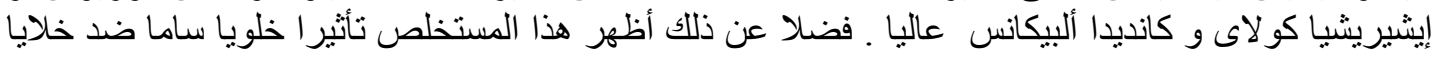

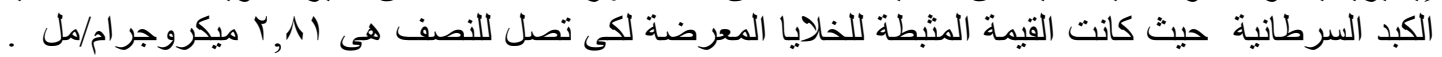

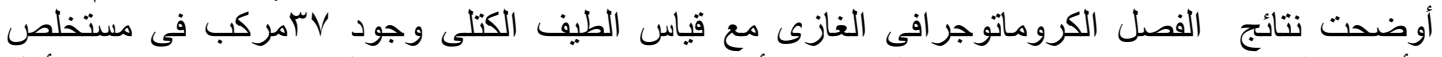

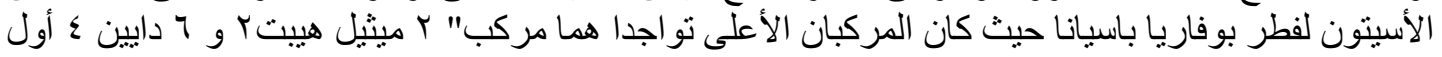

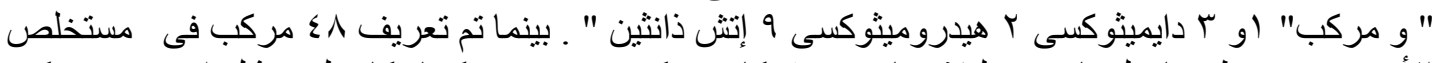

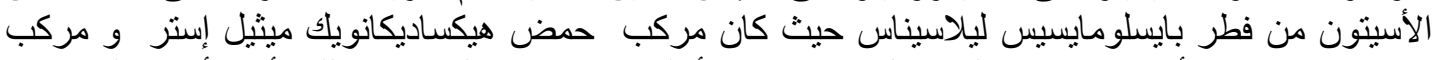

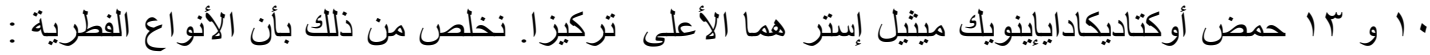

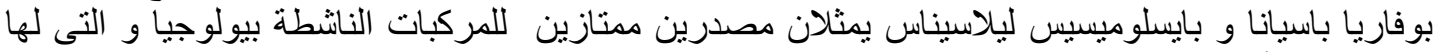

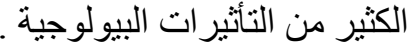

